\title{
Perancangan Sistem Informasi Monitoring Dosen Wali Menggunakan ASP.NET Signal R
}

\author{
Monitoring System Design Information \\ Using The Guardian Lecturer Asp.NET Signal R \\ Norhikmah \\ STMIK AMIKOM Yogyakarta \\ E-mail: hikmah@amikom.ac.id
}

\begin{abstract}
Abstrak
Didalam perguruan tinggi pihak akademik memiliki kewajiban untuk menunjuk seorang dosen untuk menjadi dosen wali dari beberapa mahasiswa, dosen wali diperuntukan untuk memberikan nasehat dan saran selama proses kegiatan akademik mahasiswa perwalian, selama menjadi dosen wali mengalami kendala dalam berkomunikasi dengan mahasiswa dikarenakan didalam aplikasi dosen wali yang digunakan sekarang belum ada fitur chatting untuk berkomunikasi antara dosen wali dengan mahasiswa perwalian, maka dari itu dibutuhkan sistem monitoring dosen wali dengan menggunakan ASP.net Signal $R$, dan perancangan sistem menggunakan UML yaitu usecase, activity diagram, dan class diagram. Hasil dari penelitian ini adalah model rancangan sistem monitoring dosen wali dengan menggunakan ASP.Net Signal $R$ yang dapat memberikan kemudahan kepada mahasiswa dalam berkonsultasi kepada dosen, sehingga dosen dapat mengetahui rekam jejak konsultasi mahasiswa, dan permasalahan akademik yang dihadapi mahasiswa perwaliannya dengan menambahkan fitur chatting didalam aplikasi dosen wali, fitur chatting tersebut bertujuan untuk merekam jejak / monitoring/ komunikasi antara dosen wali dengan mahasiswa yang dimana rekam jejak konsultasi mahasiswa tersebut disimpan secara realtime.
\end{abstract}

Kata Kunci - Konsultasi, Dosen, Wali, Chatting, Realtime

\begin{abstract}
In college academic authorities have an obligation to appoint a lecturer to become a lecturer guardians of some students, faculty trustee intended to provide advice and suggestions during the academic activities of students guardianship, long a guardian lecturers have problems in communicating with the students because in the application lecturers guardian yet their use chat feature to communicate between faculty trustee with the students, and therefore required faculty trustee monitoring system using ASP.net Signal R, and system design using UML is use case, activity diagrams, and class diagrams. Results from this study is a model faculty trustee monitoring system design using ASP.Net Signal $R$ to provide convenience to the student in consultation to teachers, so teachers can know the track record of consulting students, and academic problems faced by students ward by adding a chat feature inside application faculty trustee, the chat feature is intended to record trace / monitoring / communication between faculty trustee with a college student consultation where the track record is stored in realtime.
\end{abstract}

Keywords - Consulting, Lecturer, Mayor, Chatting, Realtime 


\section{PENDAHULUAN}

Didalam perguruan tinggi pihak akademik memiliki kewajiban untuk menunjuk seorang dosen untuk menjadi dosen wali dari beberapa mahasiswa. Dosen yang menjadi wali diperuntukan untuk memberikan nasehat dan saran selama proses kegiatan akademik mahasiswa, selama menjadi dosen wali mengalami kendala dalam berkomunikasi dengan mahasiswa yaitu didalam aplikasi dosen wali yang digunakan sekarang belum ada fitur chatting untuk berkomunikasi.

Komunikasi interpersonal adalah interaksi keseharian merefleksikan keragaman sosial dalam jalinan komunikasi yang apik[1]. Maka dari itu dibutuhkan sistem monitoring dosen wali dengan menggunakan ASP.net Signal R.

Sistem Monitoring dosen wali dengan menggunakan ASP.Net Signal R adalah library untuk pengembang asp.net yang menyederhanakan proses penambahan fungsi realtime untuk aplikasi web. Fungsi realtime adalah kemampuan server meng-update konten langsung ke klien [2].

Sistem konsultasi dan laporan pembimbingan tugas akhir adalah sistem sudah dapat diselesaikan dan dapat dijalankan pada IT Center. Hasil dari laporan pembimbingan tugas akhir ini berupa kartu bimbingan berdasarkan inputan waktu mulai sampai selesai bimbingan. Dosen pembimbing melakukan bimbingan dengan cara download materi yang dikirim oleh mahasiswa dan memberikan komentar atau dengan cara melakukan diskusi dengan chatting. Pembimbing menyetujui untuk ujian seminar proposal dan pendadaran. Kartu bimbingan bisa diprint dan dijadikan bukti fisik mengajukan ujian seminar proposal dan pendadaran di tingkat fakultas maupun universitas [3].

Sedangkan Hasil dari penelitian ini adalah model rancangan sistem monitoring dosen wali dengan menggunakan ASP.Net Signal R yang dapat memberikan kemudahan kepada mahasiswa dalam berkonsultasi kepada dosen wali, sehingga dosen wali dapat mengetahui rekam jejak konsultasi mahasiswa, dan permasalahan akademik yang dihadapi mahasiswa perwaliannya dengan menambahkan fitur chatting didalam aplikasi dosen wali, fitur chatting tersebut bertujuan untuk merekam jejak / monitoring/ komunikasi antara dosen wali dengan mahasiswa yang dimana rekam jejak konsultasi mahasiswa tersebut disimpan secara realtime.

Rumusan masalah penelitian ini adalah bagaimana membuat model rancangan sistem informasi dosen wali menggunakan asp.net Signal R?

Tujuan penelitian sebagai berikut:

1. Membuat model rancangan atau prototipe sistem informasi monitoring dosen wali menggunakan asp.net signall $R$.

2. Untuk memudahkan mahasiswa dalam berkonsultasi dengan dosen wali.

3. Untuk mengetahui rekam jejak konsultasi mahasiswa perwalian.

Batasan penelitian sebagai berikut:

1. Model rancangan atau prototipe sistem informasi monitoring dosen wali hanya menggunakan asp.net signall $R$.

2. Penelitian ini dilakukan di STMIK AMIKOM YOGYAKARTA

Dalam melakukan penulisan ini perlu diberikan beberapa tinjauan pustaka dan landasan teori sebagai dasar penelitian, beberapa penelitian yang berkaitan dengan penelitian sebagai berikut:

Sri Handayani Ningsih dan Wahyu Pujiyono, 2010, Paper yang berjudul"Sistem Konsultasi dan Laporan Pembimbingan Tugas Akhir", ISSN: 1979-2328, SemnasIF, UPN "Veteran" Yogyakarta, 22 Mei 2010. Sistem konsultasi dan laporan pembimbingan tugas akhir adalah sistem sudah dapat diselesaikan dan dapat dijalankan pada IT Center. Hasil dari laporan pembimbingan tugas akhir ini berupa kartu bimbingan berdasarkan inputan waktu mulai sampai selesai bimbingan. Dosen pembimbing melakukan bimbingan dengan cara download materi yang dikirim oleh mahasiswa dan memberikan komentar atau dengan cara melakukan diskusi dengan 
chatting. Pembimbing menyetujui untuk ujian seminar proposal dan pendadaran. Kartu bimbingan bisa diprint dan dijadikan bukti fisik mengajukan ujian seminar proposal dan pendadaran di tingkat fakultas maupun universitas [3].

Ramayasa I Putu, Arnawa Ida Bagus Ketut Surya, paper yang berjudul: "Perancangan Sistem Monitoring Pengerjaan Skripsi Pada STMIK STIKOM BALI Berbasis Web" Konferensi Nasional Sistem \& Informatika 2015 STMIK STIKOM Bali, 9 - 10 Oktober 2015. Perancangan sistem ini akan digunakan oleh dosen pembimbing, pihak admin dan mahasiswa. Dosen pembimbing bertugas untuk melakukan bimbingan skripsi dan menentukan estimasi kelulusan mahasiswa. Pihak admin akan mengetahui perkembangan pengerjaan skripsi mahasiswa [4].

I Nyoman Aro Ardiadi, Dian Pramana, IB Ketut Surya Arnawa, paper yang berjudul "Sistem Monitoring Skripsi STMIK STIKOM Bali berbasis ASP.Net", JOSIKOM,Vol 1, No 1,2015. STMIK STIKOM BALI skripsi merupakan sebuah istilah untuk karya ilmiah yang menjadi persyaratan untuk mendapatkan gelar status Sarjana Satu (SI). Mahasiswa yang telah mengambil mata kuliah skripsi dapat berkonsultasi kepada calon dosen pembimbing mengenai ide skripsi yang akan diajukan, kemudian mahasiswa tersebut wajib mengajukan judul skripsi melalui SION. Judul yang telah diajukan tersebut akan diverifikasi untuk memastikan originalitas dan kualitasnya. Bagi mahasiswa yang judulnya telah diterima wajib melakukan proses bimbingan kedosen pembimbing yang telah ditentukan hingga dinyatakan siap untuk maju sidang. Sebelumnya sudah pernah dilakukan penelitian mengenai skripsi di STMIK STIKOM Bali. Namun dari penelitian masih terdapat kekurangan. Akses yang diberikan hanya dibatasi mahasiswa dan dosen, pengerjaan skripsi tersebut. Sistem ini dapat membantu pihak program studi,dosen pembimbing, orang tua wali dan mahasiswa dalam melihat dan mengontrol perkembangan proses pengerjaan skripsi tersebut [5].

Syaiful Hendra,Sri Kusumadewi, paper yang berjudul " Perancangan Aplikasi Konseling Mahasiswa Menggunakan Metode Case Based Reasoning" Prosiding SNATIF ke - 2. 2015. Aplikasi konseling mahasiswa digunakan sebagai tools dalam proses konseling mahasiswa yang bermasalah. Metode penalaran dalam penelitian ini menggunakan metode Case Based Reasoning (CBR). Penelitian dimulai dari tahap pengambilan data kasus konseling mahasiswa dari beberapa narasumber dan pakar konseling. Selanjutnya dibuatkan attribut yang sesuai dengan proses konseling mahasiswa. Tahapan pengambilan keputusan pada penelitian ini dilakukan sesuai dengan siklus CBR yaitu retrieve, reuse, revise, retain. Pada proses retrieve kasus yang akan diuji dibandingkan dengan kasus yang terdapat dalam basis kasus melalui perhitungan similaritas, dan hasil dari perhitungan tersebut difilter menggunakan nilai treshold (ambang batas). Selanjutnya dilakukan tahapan perancangan aplikasi mulai dari konteks diagram, DFD, ERD, Database Realtional dan Desain Interface. Hasil dari penelitian ini adalah perancangan yang dibuat dapat diterapkan dalam tahap implementasi konseling mahasiswa bermasalah oleh Dosen Pembimbing Akademik [6].

\subsection{Landasan Teori}

Bimbingan adalah bantuan yang diberikan kepada individu (peserta didik) agar dengan potensi yang dimiliki mampu mengembangkan diri secara optimal dengan jalan memahami diri, memahami lingkungan, mengatasi hambatan guna menentukan rencana masa depan yang lebih baik [7].

Asp.net Signal R adalah library untuk pengembang asp.net yang menyederhanakan proses penambahan fungsi realtime untuk aplikasi web. Fungsi realtime adalah kemampuan server mengaupdate konten langsung keklient. SignalR dapat digunakan untuk menambahkan fungsi “ real-time" untuk aplikasi asp.net, contoh aplikasi chatting, setiap kali pengguna refresh halaman web untuk melihat data baru, contoh termasuk dashboard dan aplikasi pemantaun, aplikasi kolaboratif (seperti mengedit dokumen secara silmultan), update kemajuan pekerjaan dalam bentuk real-time,dan juga memungkikan untuk jenis baru aplikasi yang membutuhkan update frekuensi tinggi dari server, misal real-time game,contoh kasus melihat permainan ShootR [2]. 
Dosen wali seorang dosen tetap disebuah perguruan tinggi yang ditunjukan oleh pihak civitas akademik untuk menjadi wali beberapa mahasiswa.

Monitoring didefinisikan sebagai siklus kegiatan yang mencakup pengumpulan, peninjauan ulang, pelaporan, dan tindakan atas informasi suatu proses yang sedang diimplementasikan [8].

\section{METODE PENELITIAN}

Dalam menyelesaikan masalah penelitian ini, beberapa langkah yang perlu dilakukan sebagai metode penelitian sebagai berikut:

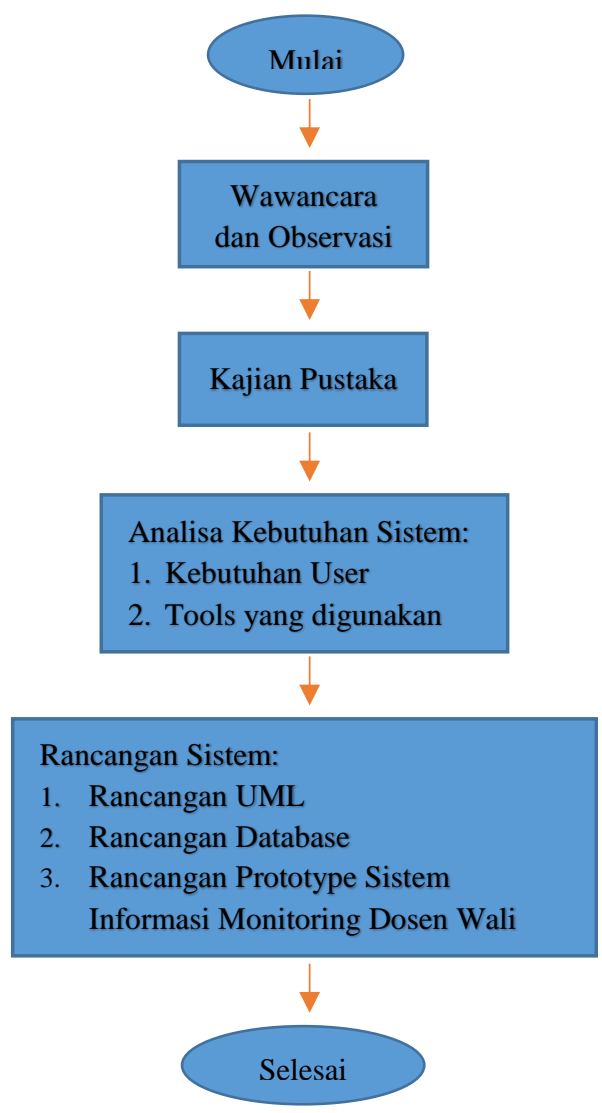

Gambar 1. Alir Diagram Penelitian

Pada Gambar 1 diatas terdapat beberapa tahapan dalam penelitian yang dilakukan, Berikut Penjelasannya:

1. Wawancara dan observasi untuk mengidentifikasi permasalahan dan kebutuhan sistem monitoring dosen wali

2. Tinjauan Pustaka yang mendukung penelitian perancangan prototipe sistem informasi monitoring dosen wali

3. Pengumpulan kebutuhan dari kebutuhan data monitoring dosen wali dan mahasiswa sampai tools apa saja yang digunakan

4. Membangun aplikasi berupa prototipe sistem informasi monitoring dosen wali

5. Hasil: Berupa model rancangan atau prototipe sistem informasi monitoring dosen wali. 
Citec Journal, Vol. 3, No. 3, Mei 2016 - Juli 2016

\section{HASIL DAN PEMBAHASAN}

Perancangan sistem yang digunakan dalam penelitian ini adalah 3 jenis UML yaitu: Use case, Activity diagram, dan Class diagram dengan penjelasan gambar sebagai berikut:

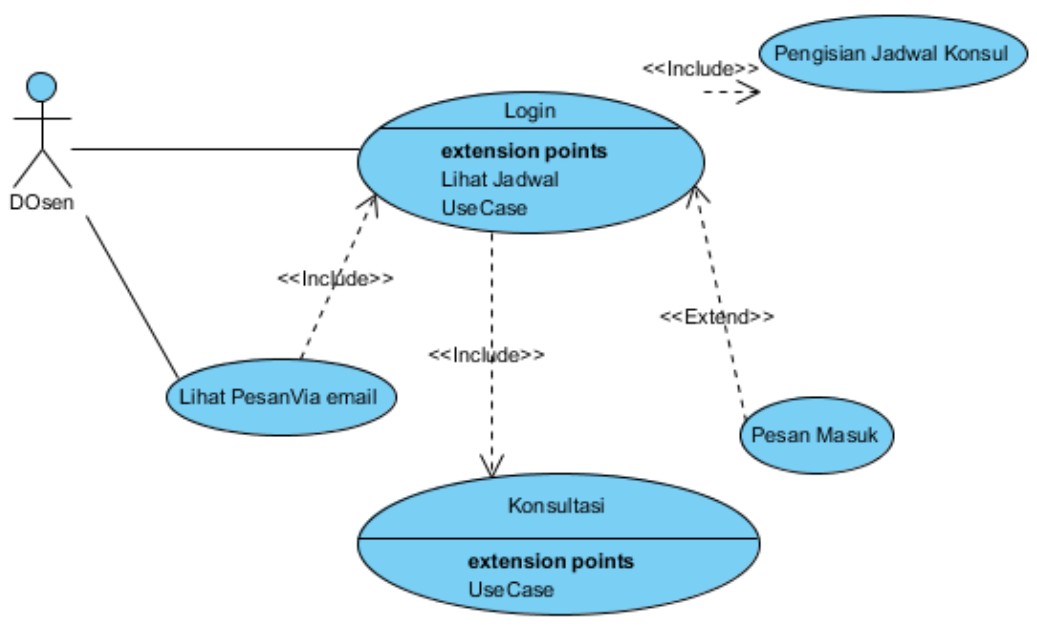

Gambar 2. Usecase Dosen Wali

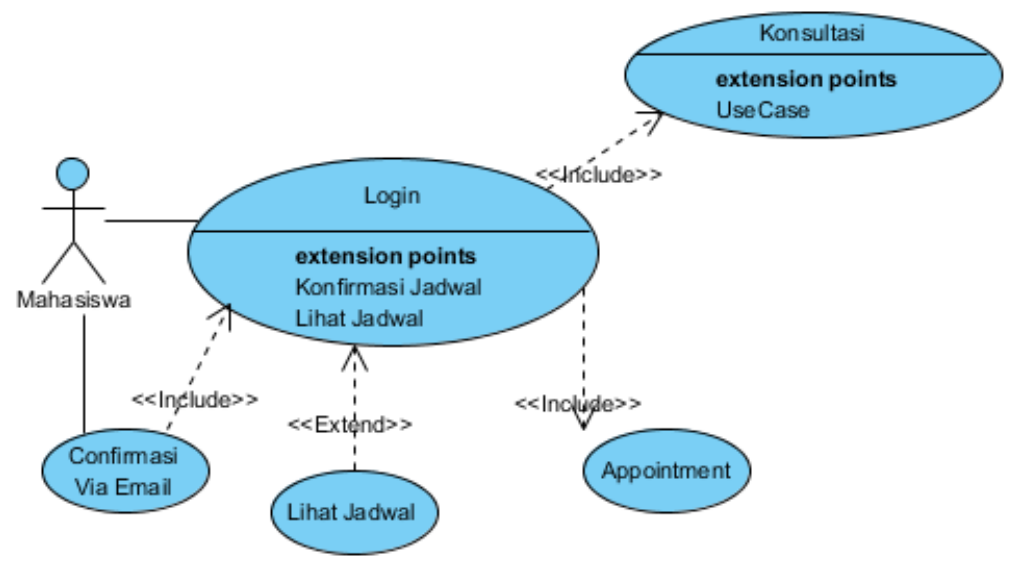

Gambar 3. Usecase Mahasiswa

Gambar 2 dan 3 adalah gambar usecase dosen wali dan mahasiswa diantara lain:

1. Dosen memiliki hak akses untuk mengisi jadwal konsultasi, melihat pesan yang telah dikirim mahasiswa perwaliannya, dan konsultasi.

2. Mahasiswa perwalian memiliki hak akses melihat jadwal dosen wali, balasan pesan dari dosen wali dan membuat pesan untuk dosen wali, membuat janjian sebelum chatting / konsultasi dengan dosen wali, dan konsultasi dengan dosen wali. 


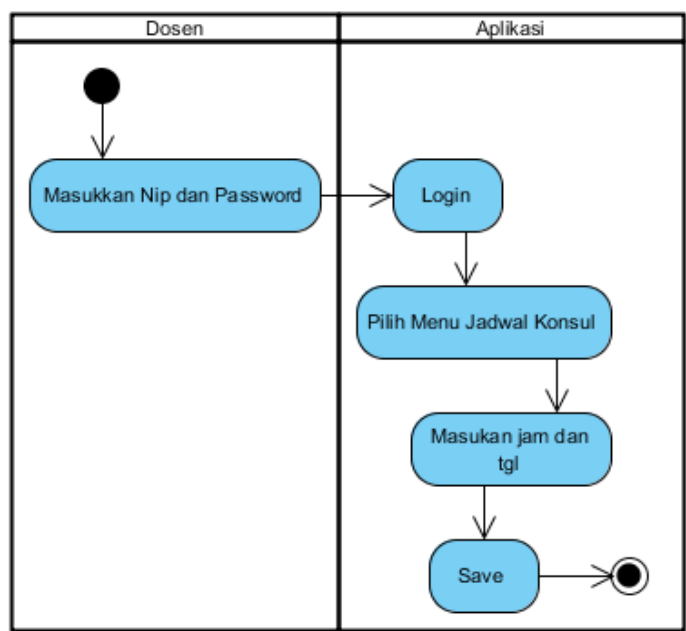

Gambar 4. Activity Diagram Setting Jadwal Konsultas

Gambar 4 merupakan activity diagram untuk men-setting jadwal konsultasi dosen, yang diisi oleh dosen wali sebelum ditampilkan oleh sistem, berikut langkah-langkah dalam mensetting jadwal konsultasi yaitu:

1. Dosen diwajibkan terlebih dahulu login dengan memasukkan nip dan password.

2. Jika berhasil login pilih menu dibagian menu utama sebelah kiri”Jadwal Konsul".

3. Memilih jam dan tanggal yang bisa digunakan untuk konsul.

4. Jika sudah selesai memilih jam dan tanggal, silahkan pilih save, maka jadwal akan terpublish/tampil kemenu janjian konsul mahasiswa perwalian.

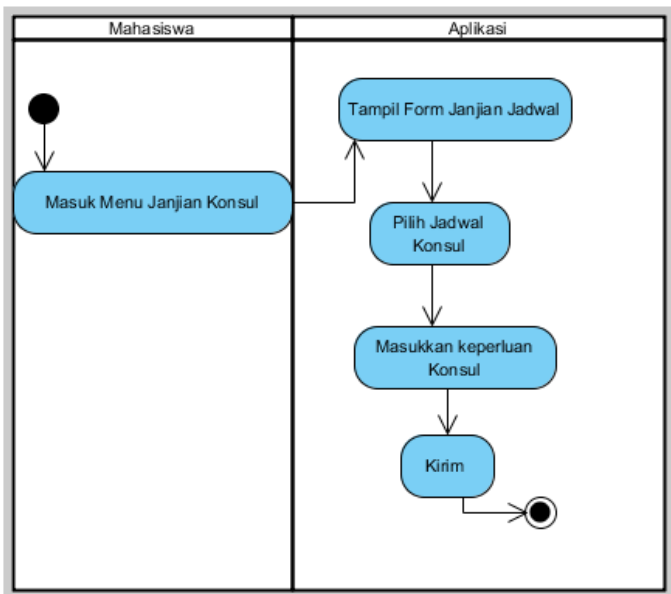

Gambar 5. Activity Diagram Appointment Konsultasi

Gambar 5 merupakan activity diagram appointment konsultasi, yang bertujuan untuk membuat janji dengan dosen wali sebelum berkonsultasi, berikut langkah-langkah dalam membuat appointment dengan dosen wali:

1. Pilih menu janjian konsul.

2. Pilih jadwal konsul yang sudah ditentukan oleh dosen wali.

3. Masukkan keperluan kenapa anda ingin konsultasi dengan dosen wali. 
Citec Journal, Vol. 3, No. 3, Mei 2016 - Juli 2016

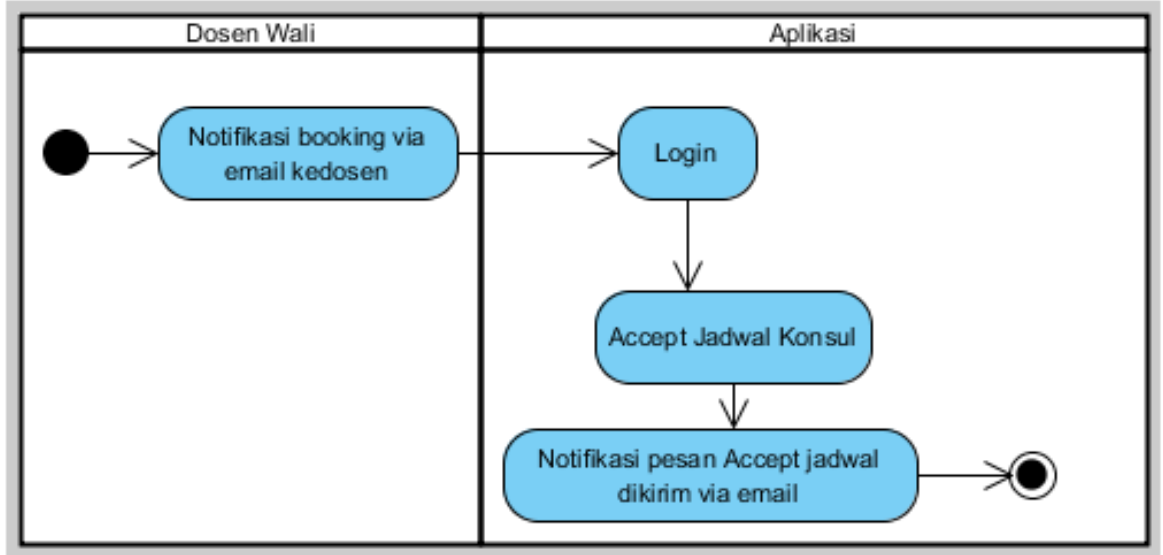

Gambar 6. Activity Diagram Message Appointment via Email

Gambar 6 merupakan notification lewat email dosen wali maupun di sistem dosen wali. Untuk meng-accept/cancel/pending appointment mahasiswa perwalian, seorang dosen diwajibkan terlebih dahulu login ke aplikasi dosen wali.

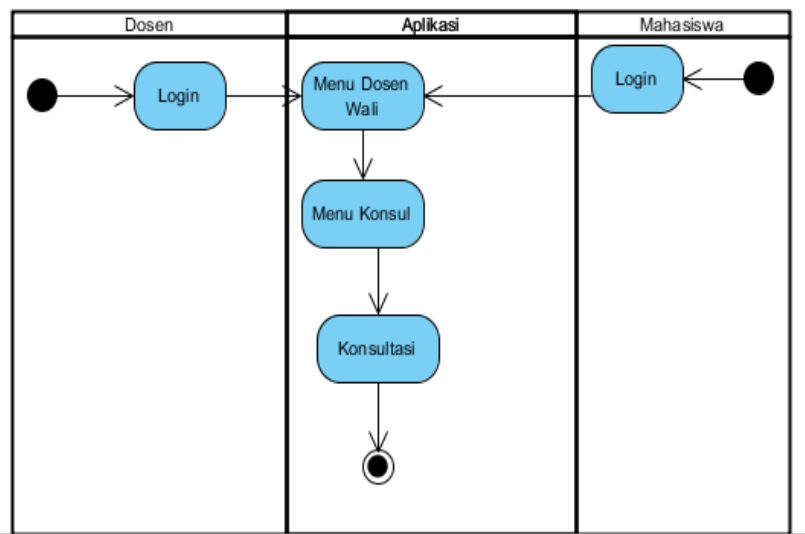

Gambar 7. Activity Diagram Konsultasi

Gambar 7 adalah activity diagram konsultasi antara dosen dengan mahasiswa, yang dimana message dosen dengan mahasiswa akan disimpan didatabase secara real time.

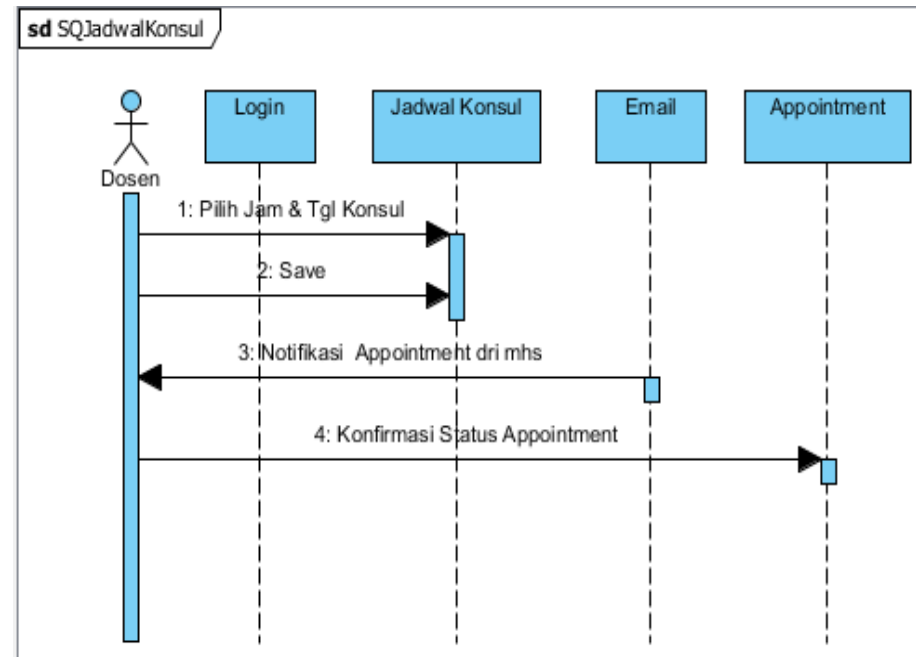

Gambar 8. Sequence Setting Jadwal Konsultasi 
Gambar 8 menggambarkan alur proses men-setting jadwal konsultasi yang dilakukan oleh dosen wali.

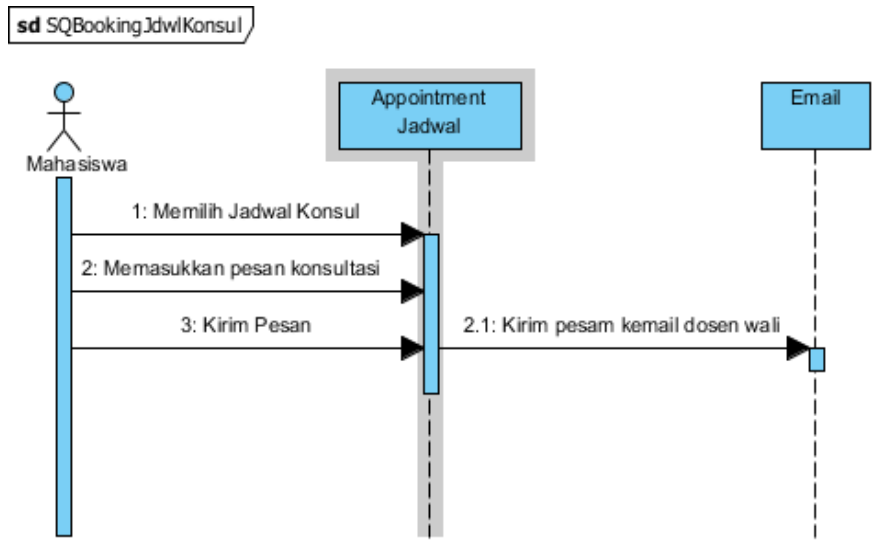

Gambar 9. Sequence Appointment Jadwal Konsultasi

Gambar 9 adalah alur proses appointment jadwal konsultasi yang dilakukan oleh mahasiswa.

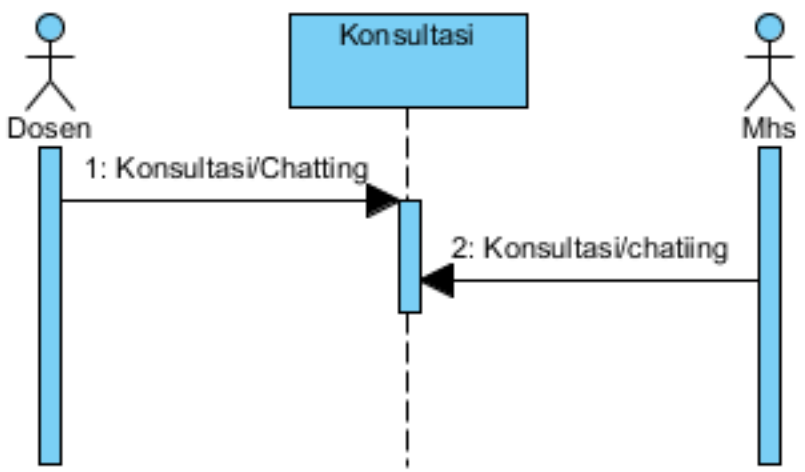

Gambar 70. Sequence Konsultasi

Gambar 10 adalah alur proses konsultasi antara dosen dengan mahasiswa. 
Citec Journal, Vol. 3, No. 3, Mei 2016 - Juli 2016

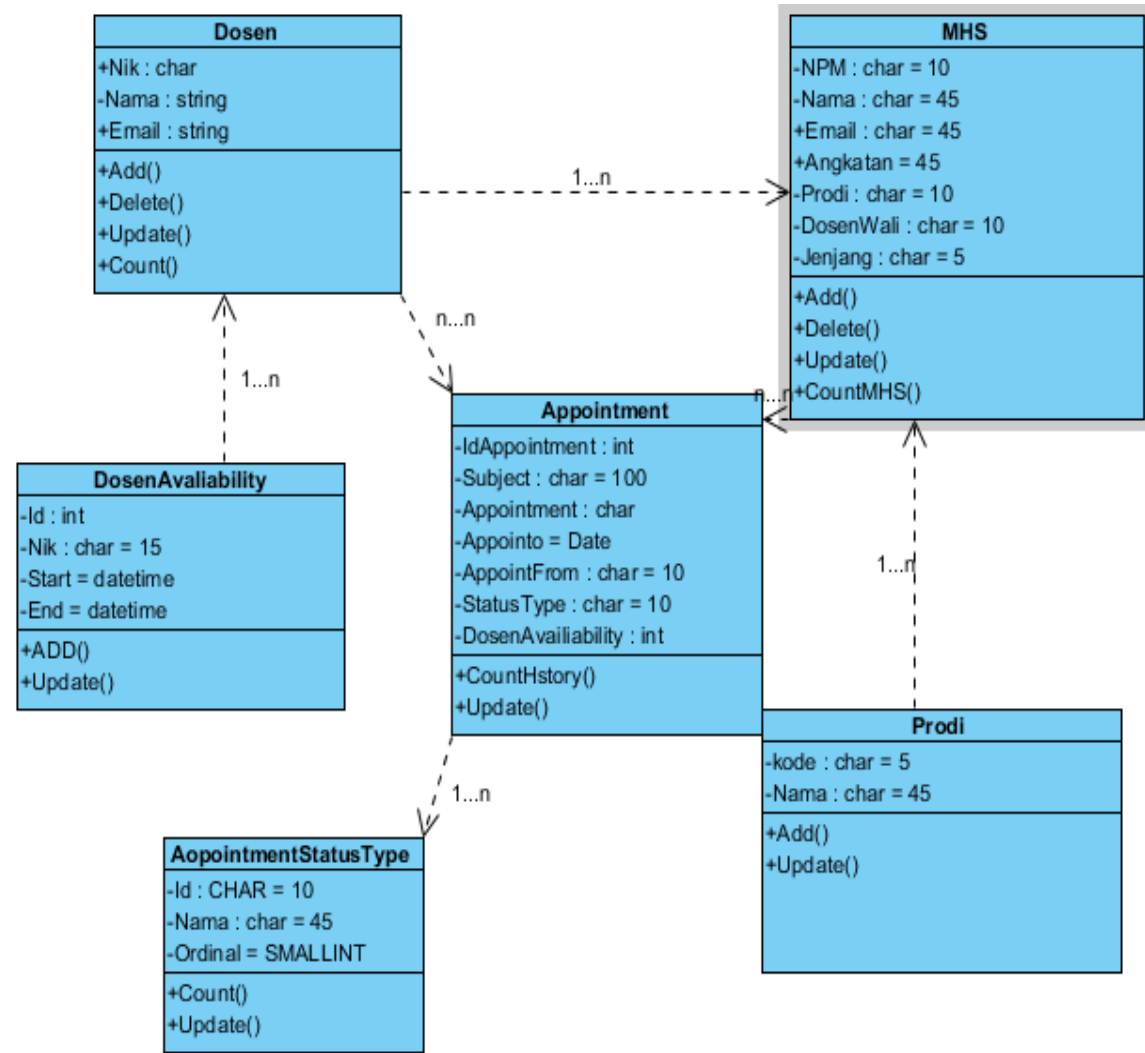

Gambar 11. Class Diagram Dosen Wali

Gambar 11 merupakan gambaran class digunakan dalam membangun rancangan prototipe dosen wali.class-class yang ada di diagram dosen wali yaitu class dosen, dosen availbility, appointment, mahasiswa, dan prodi. 


\subsection{Rancangan Database}

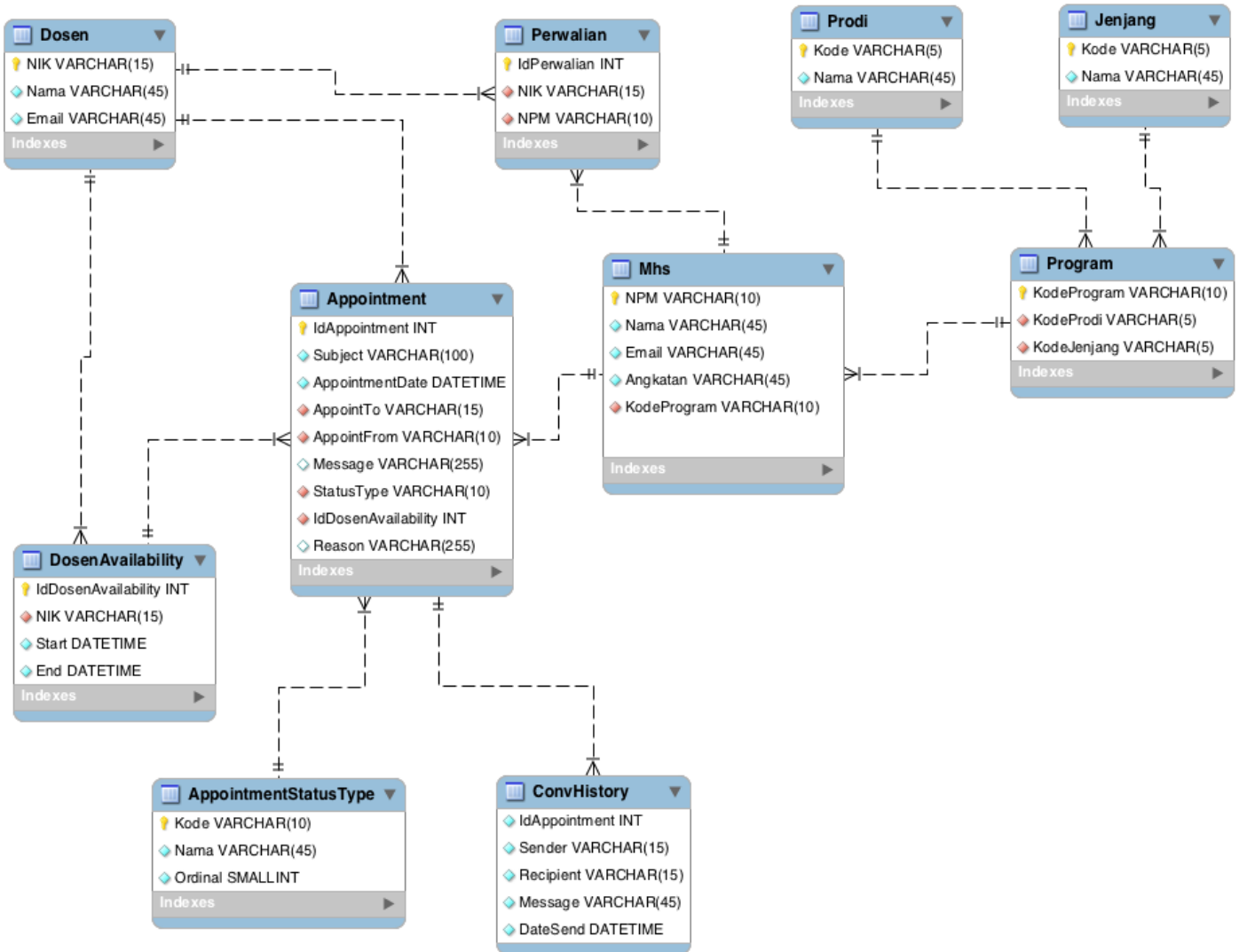

Gambar 12. Rancangan Database

Gambar 12 adalah gambar rancangan database dosen wali, yang terdiri dari 10 tabel yaitu:

1. Tabel Dosen

2. Tabel Perwalian

3. Tabel Mahasiswa

4. Tabel Prodi

5. Tabel Jenjang

6. Tabel Program

7. Tabel Appointment

8. Tabel CovHistory

9. Tabel AppointmenS.T

10. Tabel Dosen Avaibility
: Tabel yang menyimpan data dosen secara keseluruhan.

: Tabel yang menyimpan data dosen wali.

: Tabel yang menyimpan data mahasiswa yang menjadi walinya.

: Tabel yang menyimpan data prodi.

: Tabel yang menyimapan data jenjang pendidikan.

: Tabel yang menyimpan data program Studi.

: Tabel yang menyimpan data appoitment dengan mahasiswa.

: Tabel yang menyimpan data konsultasi.

: Tabel yang menyimpan jenis konsultasi.

: Tabel yang menyimpan data status dosen untuk berkonsultasi.

\subsection{Hasil Rancangan prototipe}

Rancangan prototipe monitoring sistem informasi dosen wali dengan menggunakan Asp.Net signal $R$, sebagai berikut:

1. Sebelum masuk ke aplikasi monitoring dosen wali, dosen maupun mahasiswa diwajibkan login terlebih dahulu, login sesuai nip dan nim masing-masing, setelah login maka akan tampil gambar sebagai berikut: 
Citec Journal, Vol. 3, No. 3, Mei 2016 - Juli 2016

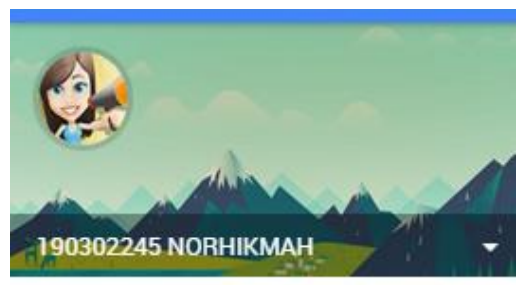
A Beranda
- Atur Jadwal
트 Konsultasi

Gambar 13. Menu Utama

Gambar 13 adalah menu utama dosen yang terdiri dari menu atur jadwal, konsultasi, dan pesan, dengan penjelasan sebagai berikut:

a. Atur jadwal adalah menu dimana dosen dapat memilih/menentukan jadwal kapan mahasiswa dapat berkonsultasi secara langsung melalui fitur konsultasi, seperti gambar 14 dan 15 di bawah ini:

\section{Atur Waktu Konsultasi}

Keterangan

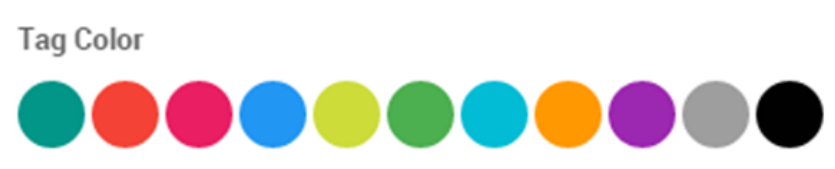

TAMBAHKAN BATAL

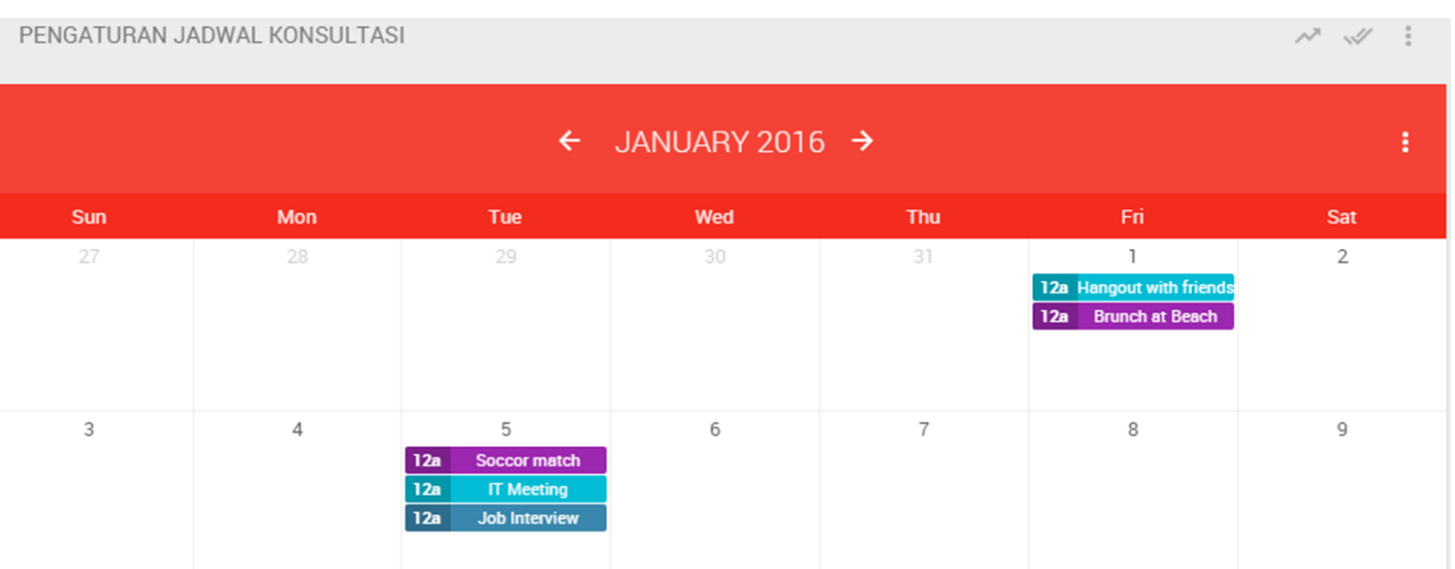

Gambar 14. Atur Jadwal 


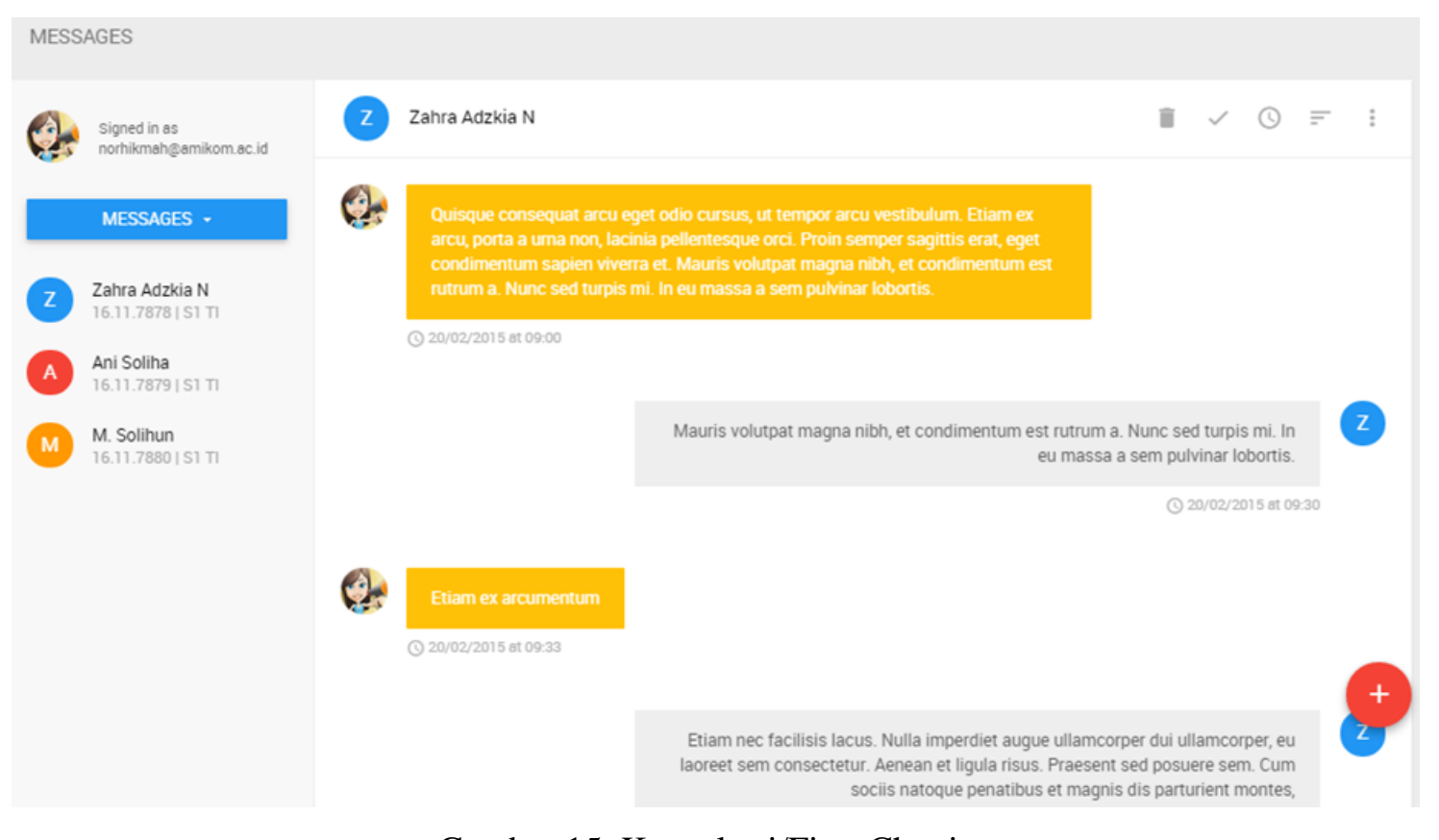

Gambar 15. Konsultasi/Fitur Chatting

Gambar 15 adalah gambar percakapan/komunikasi antara dosen wali dengan mahasiswa, teknologi yang digunakan dalam membuat fitur konsultasi/chatting diatas adalah menggunakan asp.net Signal R. Yang dimana record messange disimpan secara real time dan bisa dibuka kembali ketika dibutuhkan untuk melihat track record konsultasi dengan mahasiswa perwalian.

b. Sebelum konsultasi dengan dosen wali, mahasiswa diwajibkan terlebih dahulu melakukan appointment, notifikasi pesan appointment mahasiswa akan masuk melalui email dan sistem akan memberikan notifikasi pesan masuk dari mahasiswa yang ingin berkonsultasi. Dosen dapat meng-accept/cancel/pending appointment tersebut dengan cara masuk ke aplikasi dosen wali, buka fitur pesan atau notifikasi pesan, pilih accept/cancel/pending appointment selanjutanya dikirim mahasiswa perwalian, maka notifikasi pesan masuk kemail mahasiswa tersebut, seperti contoh gambar notifikasi pesan masuk diaplikasi dosen wali di bawah ini:

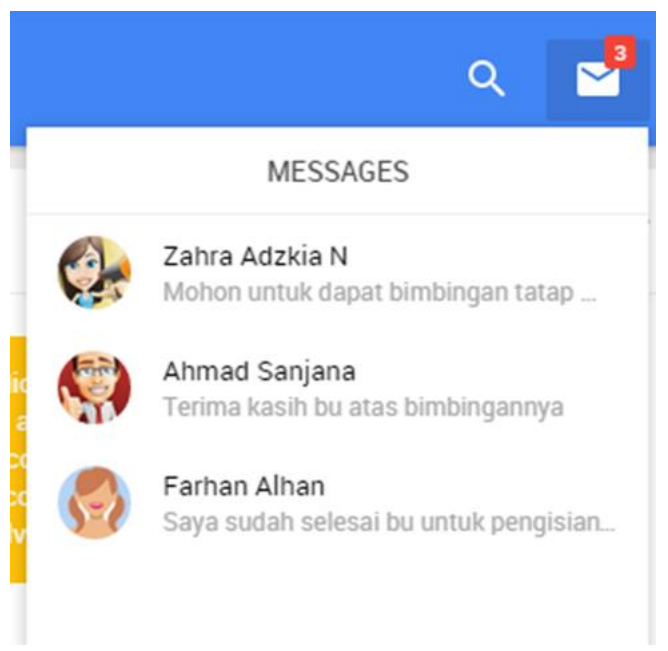

Gambar 16. Notifikasi Pesan Masuk 
Citec Journal, Vol. 3, No. 3, Mei 2016 - Juli 2016

ISSN: 2354-5771

c. Dosen dapat melihat pesan masuk, membalas pesan atau membuat pesan baru, yang dimana jika pesan tersebut dikirim maka akan masuk ke-inbox mail. Seperti gambar dibawah ini:

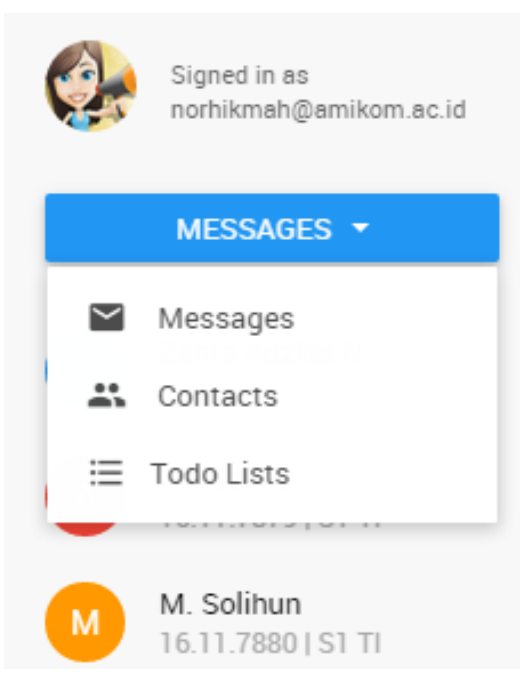

Gambar 17. Membuat Pesan

\section{KESIMPULAN}

Kesimpulan dari penelitian ini berupa model rancangan atau prototipe sistem monitoring dosen wali dengan menggunakan ASP.Net Signal R yang dapat memberikan kemudahan kepada mahasiswa dalam berkonsultasi kepada dosen, sehingga dosen dapat mengetahui rekam jejak konsultasi mahasiswa, dan permasalahan akademik yang dihadapi mahasiswa perwaliannya dengan menambahkan fitur chatting di dalam Aplikasi Dosen Wali.

\section{SARAN}

Saran untuk penelitian ini adalah membuat sebuah aplikasi sistem monitoring dosen wali.

\section{Ucapan Terima Kasih}

Penulis mengucapkan terima kasih kepada P3M STMIK AMKOM Yogyakarta yang telah memberi dukungan financial terhadap penelitian ini.

\section{DAFTAR PUSTAKA}

[1] Wood, J. T., 2013, Komunikasi Interpersonal Interaksi Keseharian (Ed 6), Salemba Humanika, Jakarta.

[2] Fletcher, P., 2014, Introduction to Signal R, http://www.asp.net/signalr/overview/gettingstarted/introduction-to-signalr, Diakses tanggal 30 Desember 2015.

[3] Handayaningsih, S., Pujiyono, W., 2010, Sistem Konsultasi dan Laporan Pembimbingan Tugas Akhir, SemnasIF UPN “Veteran”, Yogyakarta, 22 Mei 2010.

[4] Ramayasa, I. P., Arnawa, I. B. K. S., 2015, Perancangan Sistem Monitoring Pengerjaan Skripsi Pada STMIK STIKOM BALI Berbasis Web, Konferensi Nasional Sistem \& Informatika 2015, Bali, 9 - 10 Oktober 2015. 
[5] Ardiadi, I. N. A., Pramana, D., Arnawa, I. B. K. S., 2015, Sistem Monitoring Skripsi STMIK STIKOM Bali berbasis ASP.Net, JOSIKOM: Jurnal Online Sistem Komputer, No. 1, Vol. 1.

[6] Hendra, S., Kusumadewi, S., 2015, Perancangan Aplikasi Konseling Mahasiswa Menggunakan Metode Case Based Reasioning, Prosiding SNATIF ke-2, Kudus, 12 September 2015.

[7] Ahmadi, A., 1999, Psikologi Sosial, Penerbit Rineka Cipta, Jakarta.

[8] Corps M., 2005, Design, Monitoring, Evaluatin Guidebook. 